\title{
Use of Nanomaterials for Marine Bioremediation: A Perspective
}

\section{Cappello $\mathrm{S}^{1 *}$ and Mancini $\mathrm{G}^{2}$}

${ }^{1}$ Institute of Biological Resources and Marine

Biotechnology (IRBIM)-CNR of Messina, Italy

${ }^{2}$ Department of Electric, University of Catania, Italy

*Corresponding author: Cappello S, Institute of

Biological Resources and Marine Biotechnology (IRBIM)-

CNR of Messina, Sp. San Raineri, 86 - 98122 Messina,

Italy

Received: J anuary 21, 2019; Accepted: J anuary 29,

2019; Published: February 05, 2019

\section{Perspective}

One of the most challenging task of the $21^{\text {st }}$ Century is to develop new eco-friendly, sustainable and economically-sound technologies to clean up the environment from contaminants. In the last years, different physical, chemical and biological technologies have specifically focused on actions to protect and restore marine environment (sediment and/or water) from pollutants. Many of these technologies have played a central role in marine oil spill response contingency plans.

Bioremediation techniques have been proved to be a new an effective method for cleaning up residual pollutants in a variety of environments and a quite flexible management option to be implemented, also at a large scale, in marine ecosystem.

Stimulation of the growth of indigenous microorganisms (biostimulation) or inoculation of foreign oil-degrading bacteria (bioaugmentation) were recognized as effective measures for accelerating the detoxification of a polluted site with a minimal impact on the ecological system [1]. Although bioremediation provides an excellent and flexible recovery strategy for different pollutants, it is poorly effective when dealing with high concentration of the pollutants and xenobiotics or refractory compounds, causing unsustainable treatment efficiencies and recovery time [2]

In this context the development of nanotechnology and the integration of the use of Nanomaterials (NMs) and Nanoparticles (NPs) can represent [3] a promising innovation able to enhance the bioremediation action and to go beyond the actual limitations for in-situ or ex-situ applications. The combined approach appears to embrace a wider range of potential applications with reduced costs and increased control of undesired byproducts formation [4]. Hazardous and radioactive waste depollution, groundwater and wastewater treatment, heavy metal and hydrocarbons contaminated sediments remediation are only few of the most known potential applications of Nanomaterials (NMs) in bioremediation processes [5].

NMs exhibit unique physical and chemical properties (eg morphology, particle size distribution, specific surface area, surface charge and crystallographic characterization) and according to their synthesis method, they can be identified as metal nanoparticles (NPs; eg. Pt, Rh, Pd, Ir, Ag, Au, Cu, Co, Ni, FeNi, $\mathrm{Cu}_{3} \mathrm{Au}, \mathrm{CoNi}, \mathrm{CdTe}$, $\mathrm{CdSe}, \mathrm{ZnS}$ ), carbon nanomaterials (eg. fullerenes, carbon nanotube), Metal oxide NPs (eg. $\mathrm{ZnO}, \mathrm{Fe}_{2} \mathrm{O}_{3}, \mathrm{Fe}_{3} \mathrm{O}_{4}, \mathrm{MgO}, \mathrm{BaCO}_{3}, \mathrm{BaSO}_{4}$, $\mathrm{TiO}_{2}$ ), Polymer NMs (eg. polypyrrole, polyaniline), nanocomposite (eg. fluoropolymers, polyethylene glycol, polyester polyamides) and Bionanomaterials (eg. Viruses, plasmids, and protein NPs) [5].

In this context it appears fascinating the chance to apply NMs and NPs for optimizing the recovery strategies in extreme environments (with high ecological and social interest) such as the Arctic and Antarctic areas [6]. The peculiar environmental conditions of polar environments make the traditional applications of bioremediation strategies (biostimulation and/or bioaugmentation) scarcely effective due to the reduced catalytic bacterial rate; Innovative NPs and NMs can provide the needed support to biodegrading microorganisms and enhance their development by playing an important catalyst function for the activation of the accelerated biodegradation process.

An example of such approach was provided by the Italian National Research Project in Antarctica (PNRA) titled STRANGE (Integrated physical-biological-mechanical system for the recovery of oil spills in Antarctic environment; [6]) having two main goals: i) the development of new sorbent nanostructured materials [Multiwall Carbon Nanotubes (MWCNT)] to absorb oil and heavy metals hydrocarbons and to support Antarctic oil-degrading microbial flora; ii) the development of fast-response treatment, through a Membrane Bioreactor (MBR) system [7], of the oily mixture promptly recovered through the nanostructured sorbent utilizing specifically adapted hydrocarbonoclastic bacteria microbial strains.

Nanomaterials can directly catalyze degradation of different type of pollutants and toxic materials and, at the same time, can promote the development of microorganisms able to degrade different toxic; in this short overview we have highlighted the role and the importance of potential application of nanomaterials in biodegradation process $[8,4]$.

The evaluation NMs of ability in decreasing the pollution is still in progress and could potentially catalyze the most revolutionary changes in the environmental field in the coming decades According to its high potential, it is expected that the application of NMs in the recovery of chronically marine polluted area will dramatically increase in the near future playing a critical role in sustainable development of environmental management.

This work was supported by grants of National Counsel of Research (CNR) of Italy and by: i) P.O.FSE- SICILIA 2014-2020 "SANi - Salute e Ambiente - Fattori di Rischio da contaminanti nei disordini del Neurosviluppo"; ii) PNRA2015_00090 Plastic in Antarctic Environment (PLANET Project); iii) PNRA2016 NANOparticelle Polimeriche nell'ambiente marino e negli organismi 


\section{Antartici (nanoPANTA).}

\section{References}

1. Hassanshahian M, Emtiazi G, Cappello S. Isolation and characterization of crude-oil-degrading bacteria from the Persian Gulf and the Caspian Sea. Marine Pollution Bulletin. 2012; 64: 7-12.

2. Mapelli F, Scoma A, Michaoud G, Aulenta F, Boon N, Borin S, et al. Biotechnologies for marine oil spill cleanup: indissoluble ties with microorganisms. 2017; 35: 860-870.

3. Cecchin I, Reddy KR, Thorme A, Tessaro EF, Schnaid F. Nanobioremediation Integration of nanoparticles and bioremediation for sustainable remediation of chlorinated organic contaminants in soils. International Biodeterioration and Bioremediation. 2017; 119: 419-428.

4. Yadav KK, Singh JK, Gupta N, Kumar V. A Review of Nanobioremediation Technologies for Environmental Cleanup: A Novel Biological Approach. Journal of Materials and Environmental Sciences. 2017; 8: 740-757.
5. Rizwan MD, Singh M, Mitra CK, Morve RK. Ecofriendly Application of Nanomaterials: Nanobioremediation. Journal of Nanoparticles. 2014

6. Cappello S, Mancini G, Pistone A, Azzaro M, Bottino F, Genovese L, et al. STRANgE, integrated physical-biological-mechanical system for recovery in of the "oil spill" in Antarctic environment. Reviews in Environmental Science and Bio/Technology. 2014; 3(4): 369-37.

7. Cappello S, Volta A, Santisi S, Morici C, Mancini G, Quatrini P, et al. Oildegrading bacteria from a membrane bioreactor (BF-MBR) system for treatment of saline oily waste: Isolation, identification and characterization of the biotechnological potential. International Biodeterioration \& Biodegradation. 2016; 110: 235-244.

8. Patil SS, Shedbalkar UU, Truskewycz A, Chopade BA, Ball AS. Nanoparticles for environmental clean-up: A review of potential risks and emerging solutions. Environmental Technology \& Innovation. 2016; 5: 10-21.
Ann Materials Sci Eng - Volume 4 Issue 1 - 2019

ISSN : 2471-0245 | www.austinpublishing group.com

Cappello et al. @ All rights are reserved
Citation: Cappello S and Mancini G. Use of Nanomaterials for Marine Bioremediation: A Perspective. Ann Materials Sci Eng. 2019; 4(1): 1035. 